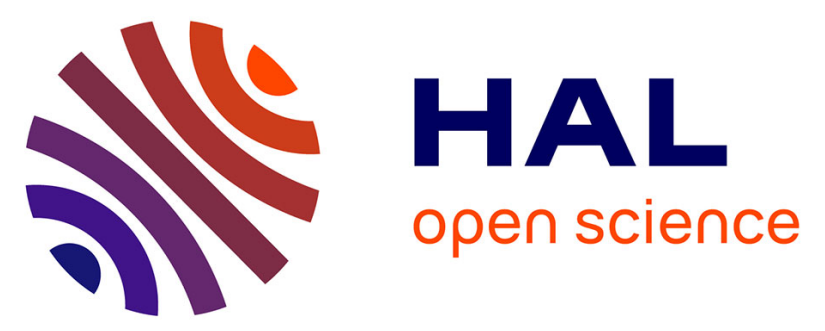

\title{
A novel 355-357delGAG mutation and frequency of connexin-26 (GJB2) mutations in Iranian patients.
}

Mohammad Hamid, Morteza Karimipoor, Morteza Hashemzadeh Chaleshtori, Mohammad Taghi Akbari

\section{- To cite this version:}

Mohammad Hamid, Morteza Karimipoor, Morteza Hashemzadeh Chaleshtori, Mohammad Taghi Akbari. A novel 355-357delGAG mutation and frequency of connexin-26 (GJB2) mutations in Iranian patients.. Journal of Genetics, 2009, 88 (3), pp.359-362. 10.1007/s12041-009-0054-6 . pasteur00750567

\section{HAL Id: pasteur-00750567 https://hal-riip.archives-ouvertes.fr/pasteur-00750567}

Submitted on 11 Nov 2012

HAL is a multi-disciplinary open access archive for the deposit and dissemination of scientific research documents, whether they are published or not. The documents may come from teaching and research institutions in France or abroad, or from public or private research centers.
L'archive ouverte pluridisciplinaire HAL, est destinée au dépôt et à la diffusion de documents scientifiques de niveau recherche, publiés ou non, émanant des établissements d'enseignement et de recherche français ou étrangers, des laboratoires publics ou privés. 


\title{
A novel 355-357delGAG mutation and frequency of connexin-26 (GJB2) mutations in Iranian patients
}

\author{
MOHAMMAD HAMID ${ }^{1}$, MORTEZA KARIMIPOOR ${ }^{1}$, MORTEZA HASHEMZADEH CHALESHTORI ${ }^{2}$ and \\ MOHAMMAD TAGHI AKBARI ${ }^{3,4 *}$ \\ ${ }^{1}$ Department of Molecular Medicine, Pasteur Institute of Iran, No. 69, Pasteur Ave, 13164 Tehran, Iran \\ ${ }^{2}$ Cellular and Molecular Research Center, Shahrekord University of Medical Sciences, Shahrekord, 88179-55786, Iran \\ ${ }^{3}$ Department of Medical Genetics, Faculty of Medical Science, Tarbiat Modares University, Tehran 14115-111, Iran \\ ${ }^{4}$ Tehran Medical Genetics Laboratory, No. 297, Taleghane Street, Tehran 1598619617, Iran
}

\begin{abstract}
Introduction
The common form of autosomal recessive non-syndromic deafness is caused by the mutation in gap junction beta 2 (GJB2) gene (GenBank M86849, OMIM\# 121011) which is located at the DFNB1 locus at 13q11. GJB2 is a small gene about 5500-bp length with two exons, of which only one contains the coding region (Kelley et al. 2000). The sequence of the coding region consists of $681 \mathrm{bp}$, encoding a gap-junction protein with 226 amino acids (Schrijver 2004).

The genetics of hearing loss is highly heterogeneous and more than 100 mutations in connexin 26 (GJB2) genes are reported to be responsible for $30 \%-40 \%$ of hereditary hearing loss in deaf subjects (Ballana et al. 2001; Schrijver 2004). The most frequent mutation $35 \mathrm{delG}$ has been detected in different populations; especially in European countries where it is established to be due to founder effect (Van Laer $e t$ al. 2001; Rothrock et al. 2003).

In this study, we performed mutation screening in 33 families who met clinical criteria of non-syndromic hereditary hearing loss (NSHHL) to evaluate the type and frequency of $G J B 2$ mutations in Iranian population.
\end{abstract}

\section{Materials and methods}

This study was conducted on 33 unrelated families affected by NSHHL were referred to our laboratory. All patients had moderate-to-profound sensorineural hearing loss. The hearing loss of patients was confirmed by audiologic testing; air and bone conduction were evaluated in frequencies of 250 , 500, 1000, 2000, 4000 and $8000 \mathrm{~Hz}$ with intensities up to

*For correspondence. E-mail: mtakbari@modares.ac.ir.
$120 \mathrm{~dB}$. The autosomal-recessive inheritance of the disease was established by construction of the pedigree. However, the hearing loss patients did not have other clinical features.

After obtaining informed consent from all participants, $5 \mathrm{~mL}$ peripheral blood was taken from patients and genomic DNA was extracted by using standard salting out method. Detection of mutations within GJB2 gene was carried out by DNA sequencing for all samples. The entire coding region of GJB2 gene (GenBank accession no. M86849) was amplified using the primers: Cx148F2 (5-CCTGTGTTGTGTGYGCATTCGTC-3) and Cx929R3 (5-CTCATCCCTCTCTCATGCTGTC-3). For PCR amplification at $2 \mathrm{~min}$, initial denaturation at $94^{\circ} \mathrm{C}$ was followed by three steps including $94^{\circ} \mathrm{C}$ for $2 \mathrm{~min}, 59^{\circ} \mathrm{C}$ for $45 \mathrm{~s}$ and $72^{\circ} \mathrm{C}$ for $2 \mathrm{~min}$ in first loop (four cycles) and $94^{\circ} \mathrm{C}$ for $1 \mathrm{~min}, 59^{\circ} \mathrm{C}$ for $30 \mathrm{~s}$ and $72^{\circ} \mathrm{C}$ for $1 \mathrm{~min}$ in second loop ( 25 cycles). Fifty $\mu \mathrm{L}$ of the PCR product was purified using PCR clean up kit (Qiagen, Hilden, Germany), and it was subjected to sequencing by chain termination method on ABI 3730 XL sequencer (Primm, Milan, Italy). The sequencing results were analysed by Chromas 2.13 software (Technelgsim, Queensland, Australia). The 342-kb del(GJB6-D13S1830) was also studied by multiplex PCR as previously described (Sadeghi et al. 2005).

\section{Results}

In this study, we analysed the frequency of $G J B 2 \mathrm{mu}-$ tations in 50 NSHHL patients from 33 unrelated Iranian families. The patients were from different parts of the country with different ethnic background. Ten mutations including 35delG, R127H, V27I+E114G, Y155X, M163V, R143W, R32H, R165W, 333-334 delAA and a novel

Keywords. hearing loss; connexin 26 (Cx26); gap junction beta-2 (GJB2); 35delG; Iranian population; human genetics. 


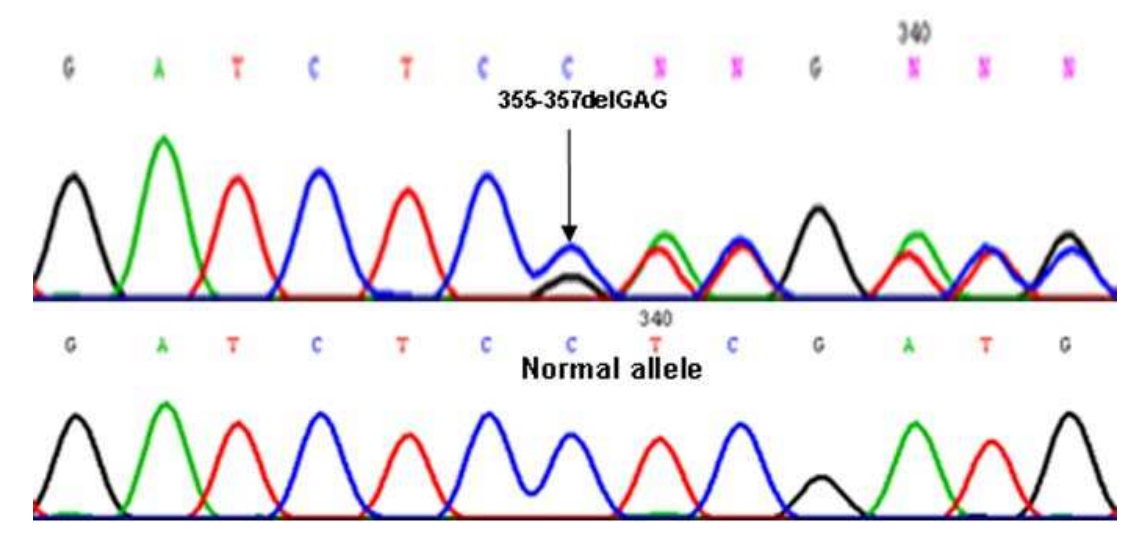

Figure 1. Nucleotide sequence of the novel variant (355-356 delGAG) compared with normal control.

Table 1. Frequency of GJB2 genotypes detected in NSHHL Iranian individuals.

\begin{tabular}{lc}
\hline Name of variants & Deaf individuals no. (\%) \\
\hline Mutation & $1(2)$ \\
M163V/wt & $4(8)$ \\
35delG/wt & $1(2)$ \\
R127H/wt & $2(4)$ \\
V27I+E114G/wt & $1(2)$ \\
R32H/35delG & $2(4)$ \\
35delG/35delG & $1(2)$ \\
R143W/R143W & $1(2)$ \\
R165W/wt & $1(2)$ \\
333-334delAA/wt & \\
Unknown mutation & $1(2)$ \\
Y155X/wt & $1(2)$ \\
Novel mutation & $16(33.3)$ \\
355-357delGAG/wt & $50(100)$ \\
Detected & \\
Total & $1(2)$ \\
Polymorphism & $3(6)$ \\
F146F +F154F/wt & $50(100)$ \\
V153I/wt & \\
S86T/S86T & \\
\hline
\end{tabular}

355-357delGAG (figure 1) were diagnosed in 16 deaf patients (33.3\%) (table 1). 35delG, R127H, V27I+E114G, Y155X, M163V, R165W, 333-334delAA and a novel 355357 delGAG were identified in $11(22 . \%)$ deaf patients in heterozygous form. Three $(6 \%)$ of hearing loss patients had $35 \mathrm{delG} / 35 \mathrm{delG}$ and R143W/R143W mutations and one (2\%) had $(\mathrm{R} 32 \mathrm{H}+35 \mathrm{delG})$ mutation in homozygous and compound heterozygous status, respectively (table 2).

Overall, the most common mutation in this cohort was $35 \mathrm{delG}$ mutation because nine out of $22(40.9 . \%)$ mutant alleles had this mutation (table 2). In addition, S86T polymorphism was observed in all patients (100\%) in homozygous form and V153I and (F154F +F146F) were detected in five families (table 2). This newly found mutation 355$357 \mathrm{delGAG}$ has not been reported previously. It causes a deletion at codon 119 and did not alter any amino acids (fig- ure 1). In this study, 20 normal subjects were used as control group and they did not show any nucleotide variation in coding region of connexin-26 gene except S86T polymorphism, which was observed in all cases.

We also analysed the 342-kb del(GJB6-D13S1830) in 10 unrelated patients with non-syndromic hearing loss that had only one GJB2 mutant allele. We did not detect any deletion among deaf person studied.

\section{Discussion}

Mutations in connexin 26 are the most common cause of NSHHL in many populations with different ethnic background. They are responsible for about $50 \%$ of autosomalrecessive hearing loss cases (Rabionet et al. 2000). In this

Table 2. Frequency of GJB2 variations detected in NSHHL Iranian individuals

\begin{tabular}{lll}
\hline Name of variants & Nucleotide change & Allele no. (\%) \\
\hline $\begin{array}{ll}\text { Mutation } \\
\text { M163V }\end{array}$ & A to G at 487 & $1(1)$ \\
35delG & Deletion of G at 35 & $9(9)$ \\
R127H & G to A at 380 & $1(1)$ \\
V27I & G to A at 79 & $2(2)$ \\
E114G & A to G at 341 & $2(2)$ \\
R32H & G to A at 95 & $1(1)$ \\
R143W & C to T at 427 & $2(2)$ \\
R165W & C to T at 493 & $1(1)$ \\
333-334delAA & del of AA at 333-335 & $1(1)$ \\
Unknown Mutation & & \\
Y155X & T to A at 465 & $1(1)$ \\
Novel mutation & & \\
355-357delGAG & del of GAG at 355-357 & $1(1)$ \\
Detected & & $22(22)$ \\
Total & & $100(100)$ \\
Polymorphism & & $1(1)$ \\
F146F & C to T at 438 & $1(1)$ \\
F154F & C to T at 462 & $100(100)$ \\
V153I & G to A at 457 3 (3) \\
S86T & GC to CG at 257-8 & \\
\hline
\end{tabular}


study, 10 different mutations were detected in NSHHL patients. Twelve out of 33 families (36.3\%) were associated with $G J B 2$ mutation in heterozygous and homozygous forms. Only four out of 33 families showed the mutations in both alleles $(12.1 \%)$, whereas eight other families revealed mutation in heterozygous form $(24.2 \%)$. In our study, the mutation detection rate in connexin 26 was higher than previous studies (Najmabadi et al. 2005; Hashemzadeh Chaleshtori 2006) This discrepancy may be due to difference in inclusion criteria for patients.

The contribution of the GJB2 gene mutations in the present Iranian NSHHL families is not much lower than Western populations, 40\% in USA (Kelley et al. 1998), 49\% in Italy and Spain (Estivill et al. 1998) and 54\% in Russian families (Posukh et al. 2005).

This study also shows $35 \mathrm{delG}$ is the most common deafness-causing mutation in the Iranian population, which is in agreement with previous reports (Najmabadi et al. 2005; Esmaeili et al. 2007). The allele frequency of $35 \mathrm{delG}$ mutation among our cases was $40.9 \%$. Compared with previous reports, it shows lower frequency of $35 \mathrm{delG}$ mutation in homozygous forms (Najmabadi et al. 2005; Esmaeili et al. 2007). This result is expected because there are different ethnic groups in our population, each one having its own characteristic allele type. Therefore, every ethnic group should be studied for the existence of mutations in other loci that might be related to deafness. As we see in Japanese, Chinese, Ashkenazi Jews and Slovak Romany populations, 35delG is rare and 235delC, 167delT and W24X were reported as founder effect (Abe et al. 2000; Lerer et al. 2001; Alvarez et al. 2005). Therefore, we will independently need to study each and every ethnic group to identify their founder mutation and private mutations.

We also detected a novel mutation which has not been reported in connexin-deafness homepage (Ballana et al. 2001). This mutation (355-357delGAG) is most probably related to deafness condition. It causes a 3-bp deletion at codon 119 in the CL domain. This mutation must be examined for functional effects. The N-terminal domain of connexin 26 associated with transmembrane domain M1 creates a charge complex that acts as a voltage sensor (Verselis et al. 1994). Moreover, the extracellular domains E1 and E2 determine the heterotypic compatibility, whereas the cytoplasmic linking domain and $\mathrm{C}$-terminal domain are involved in $\mathrm{pH}$ gating of the channel (Kelley et al. 1998).

$\mathrm{Cx} 26$ and $\mathrm{Cx} 30$ are expressed in the same inner-ear structures and connexons made of $\mathrm{Cx} 26$ and $\mathrm{Cx} 30$ are able to bind together to form heterotypic gap-junction channels (Dahl et al. 1996). Therefore, we analysed 342-kb del(GJB6D13S1830) as appropriate candidate in patients with nonsyndromic hearing loss that had only one GJB2 mutant allele. We did not detect any deletion among Iranian patients. Absence of this mutation among studied patients is similar to other studies from Iran and other countries (Gunther et al. 2003; Kalay et al. 2005; Esmaeili et al. 2007). This result supports the view that $\operatorname{del}(G J B 6-\mathrm{D} 13 \mathrm{~S} 1830)$ mutation is associated with only certain populations.

Finally, the high level of heterozygosity detected in our NSHHL patients, was also confirmed by another report from Iran (Sadeghi et al. 2005). Therefore, we would expect the contributions of other genes related to non-syndromic hearing loss to be important, and this would require further analysis in families without mutations in entire coding region of GJB2 gene. Consequently, for more characterization of the genetic contribution in these families identification of other responsible loci is required. This will help to detect carriers and patients, and facilitate prevention of deafness in multiethnic Iranian population.

\section{Acknowledgements}

We thank the staff of Dr Akbari's Medical Genetic Laboratory for their contribution for this study and also our patients for their collaboration.

\section{References}

Abe S., Usami S., Shinkawa H., Kelley P. M. and Kimberling W. J. 2000 Prevalent connexin 26 gene (GJB2) mutations in Japanese. J. Med. Genet. 37, 41-43.

Alvarez A., del Castillo I., Villamar M., Aguirre L. A., GonzalezNeira A., Lopez-Nevot A. et al. 2005 High prevalence of the W24X mutation in the gene encoding connexin-26 (GJB2) in Spanish Romani (gypsies) with autosomal recessive nonsyndromic hearing loss. Am. J. Med. Genet. Suppl. A. 137, 255258.

Ballana E., Ventayol M., Rabionet R., Gasparini P. and Estivill X. 2001 Connexins and deafness homepage. URL: http//www.iro. es/deafness/.

Dahl E., Manthey D., Chen Y., Schwarz H. J., Chang Y. S., Lalley P. A. et al. 1996 Molecular cloning and functional expression of mouse connexin-30, a gap junction gene highly expressed in adult brain and skin. J. Biol. Chem. 271, 17903-17910.

Esmaeili M., Bonyadi M. and Nejadkazem M. 2007 Common mutation analysis of GJB2 and GJB6 genes in affected families with autosomal recessive non-syndromic hearing loss from Iran: simultaneous detection of two common mutations (35delG/del(GJB6-D13S1830)) in the DFNB1-related deafness. Int. J. Pediatr. Otorhinolaryngol. 71, 869-873.

Estivill X., Fortina P., Surrey S., Rabionet R., Melchionda S., D'Agruma L. et al. 1998 Connexin-26 mutations in sporadic and inherited sensorineural deafness. Lancet 351, 394-398.

Gunther B., Steiner A., Nekahm-Heis D., Albegger K., Zorowka P., Utermann G. et al. 2003 The 342-kb deletion in GJB6 is not present in patients with non-syndromic hearing loss from Austria. Hum. Mutat. 22, 180.

Hashemzadeh Chaleshtori M., Montazer Zohour M., Hoghooghi Rad L., Pour-Jafari H., Farhud D. D., Dolati M. et al. 2006 Autosomal recessive and sporadic non syndromic hearing loss and the incidence of Cx26 mutations in a province of Iran. Iran. J. Pub. Health 35, 88-91.

Kalay E., Caylan R., Kremer H., de Brouwer A. P. and Karaguzel A. 2005 GJB2 mutations in Turkish patients with ARNSHL: prevalence and two novel mutations. Hear. Res. 203, 88-93.

Kelley P. M., Harris D. J., Comer B. C., Askew J. W., Fowler T., Smith S. D. et al. 1998 Novel mutations in the connexin 26 gene (GJB2) that cause autosomal recessive (DFNB1) hearing loss. Am. J. Hum. Genet. 62, 792-799. 


\section{Mohammad Hamid et al.}

Kelley P. M., Cohn E. and Kimberling W. J. 2000 Connexin 26: required for normal auditory function. Brain Res. Rev. 32, 184188.

Lerer I., Sagi M., Ben-Neriah Z., Wang T., Levi H. and Abeliovich D. 2001 A deletion mutation in GJB6 cooperating with a GJB2 mutation in trans in non-syndromic deafness: a novel founder mutation in Ashkenazi Jews. Hum. Mutat. 18, 460.

Najmabadi H., Nishimura C., Kahrizi K., Riazalhosseini Y., Malekpour M., Daneshi A. et al. 2005 GJB2 mutations: passage through Iran. Am. J. Med. Genet. Suppl. A. 133, 132-137.

Posukh O., Pallares-Ruiz N., Tadinova V., Osipova L., Claustres M. and Roux A. F. 2005 First molecular screening of deafness in the Altai Republic population. BMC Med. Genet. 6, 12.

Rabionet R., Zelante L., Lopez-Bigas N., D'Agruma L., Melchionda S., Restagno G. et al. 2000 Molecular basis of childhood deafness resulting from mutations in the GJB2 (connexin 26) gene. Hum. Genet. 106, 40-44.
Rothrock C. R., Murgia A., Sartorato E. L., Leonardi E., Wei S., Lebeis S. L. et al. 2003 Connexin 2635 delG does not represent a mutational hotspot. Hum. Genet. 113, 18-23.

Sadeghi A., Sanati M. H., Alasti F., Hashemzadeh Chaleshtori M. and Ataei M. 2005 Mutation analysis of connexin 26 gene and $\operatorname{del}(G J B 6-D 13 S 1830)$ in patients with hereditary deafness from two provinces in Iran. Iran. J. Biotechnol. 3. 255-258.

Schrijver I. 2004 Hereditary non-syndromic sensorineural hearing loss: transforming silence to sound. J. Mol. Diagn. 6, 275-284.

Van Laer L., Coucke P., Mueller R. F., Caethoven G., Flothmann K., Prasad S. D. et al. 2001 A common founder for the 35delG GJB2 gene mutation in connexin 26 hearing impairment. J. Med. Genet. 38, 515-518.

Verselis V. K., Ginter C. S. and Bargiello T. A. 1994 Opposite voltage gating polarities of two closely related connexins. Nature 368, 348-351.

Received 19 January 2009, in final revised form 14 July 2009; accepted 16 July 2009

Published on the Web: 8 October 2009 